\title{
Several Growth Characteristics of an Invasive Cyprinid Fish (Carassius gibelio Bloch, 1782)
}

\author{
Sait BULUT ${ }^{1}$, Ramazan MERT²*, Beklan ALGAN ${ }^{1}$, Musa ÖZBEK $^{1}$, Bülent ÜNAL ${ }^{1}$, Muhsin KONUK ${ }^{3}$ \\ ${ }^{1}$ Afyon Kocatepe University, Faculty of Science and Literatures, Biology Department, 03200, Afyonkarahisar, Turkey \\ ${ }^{2}$ Nevşehir University, Faculty of Science and Literatures, Biology Department, 50300, \\ Nevşehir,Turkey; mert@nevsehir.edu.tr ( ${ }^{*}$ corresponding author)

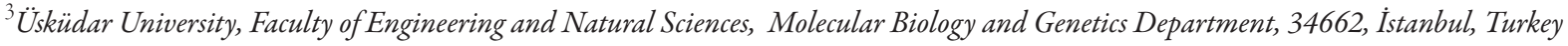

\begin{abstract}
Age composition, length-weight relationships, growth, and condition factors of the gibel carp (Carassius gibelio Bloch, 1782) were determined using specimens collected from Seyitler Reservoir between July 2005 to June 2006. A total of 149 gibel carp were observed and examined. The age composition of the samples ranged between I and VII years of age. It has been determined than $82.55 \%$ of the obtained samples are comprised of females, $16.11 \%$ is comprised of males and $1.34 \%$ is comprised of immature. The population is dominated by females able to reproduce gynogenetically. The mean fork lengths and mean weights of the population were $14.8-32.5 \mathrm{~cm}$ and 43.1-807.3 g respectively. The length-weight relation were calculated as $\mathrm{W}=0.0696 \mathrm{~L}^{2.132}, \mathrm{r}=0.838$ for females, for males $\mathrm{W}=0.2942$ $\mathrm{L}^{2.6417} \mathrm{r}=0.784$ and $\mathrm{W}=0.0274 \mathrm{~L}^{2.9382}, \mathrm{r}=0.813$ for all samples. The mean Fulton Condition Factor was calculated as 2.342 for females, 2.064 for males and 2.276 for all samples. Age-length and age-weight relations were determined according to von Bertalanffy growth equation formula. Growth parameters of the population were $\mathrm{Lt}=48.09\left[1-\mathrm{e}^{-0.093(t+0.29)}\right]$, and $\mathrm{Wt}=2323.62\left[1-\mathrm{e}^{-0.093(t+0.29)}\right]^{2.9382}$. The growth performance index value $\left(\varnothing^{\prime}\right)$ was computed as 5.37 for all specimens.
\end{abstract}

Keywords: Carassius gibelio, condition factor, invasive species, length-weight relation, Seyitler Reservoir

\section{Introduction}

Introduction of fish in freshwater ecosystems is frequently considered a practical application of fisheries management in many countries. However, these introduction initiatives can cause ecologic undesirable consequences due to intentional or unintentional introduction of invasive fish, as well as cultivation of the species targeted. Currently, C. gibelio (Kırankaya and Ekmekçi, 2013) is a typical example of introduced species. It is an omnivorous fish species which feeds on detritus, zooplankton, zoobenthos and macrophyta (Specziar et al., 1997) and continues to expand its distribution area in fresh water environments. Small specimens feed on plankton and detritus, while large specimens prefer benthos and relatively large plankton and has lived in freshwater and lagoon lakes, ponds and streams.

C. gibelio was introduced to Europe from Asia in the 17 th century. It has been already established in at least 12 European countries and range expansion of the freshwater system of Turkey (Özuluğ et al., 2004; Vetemaa et al., 2005; Özcan, 2007). The presence of gibel carp in the Turkey was not recognized until the 1980s (Baran and Ongan, 1988), probably due to its strong ppheotypicalotypical resemblance to the Carassius species introduced to Turkey: crucian carp Carassius carassius (L., 1758), and goldfish Carassius auratus (L., 1758). With developments in the identification of Carassius species, distribution of crucian carp in Turkey is presently thought to include both the Thrace region and the entire Anatolian Peninsula (Gaygusuz et al., 2007).

Invasive alien fish species have reduced the abundance of native inland water species through predation, hybridization, parasitism or competition for resources, and may alter population size, structure and ecosystem processes, such as food webs, energy flow or the hydrodynamic properties of a particular inland water ecosystem (Gurevitch and Padilla, 2004). The results of these impacts are manifested both directly and indirectly, with economic costs and risks posed to non-market goods and services as well as to public health have raised concern (Andersen et al., 2004).

Interestingly, gibel carp is one of the few fish species where the population is almost exclusively composed of females, some reproducing gynogenetically using the sperm of other species (Riehl and Baensch, 1991; Zhou et al., 2000). In addition, some even exhibit gynogenetic reproduces by the sperm of other species to activate (but not fertilize) their own eggs (Saat, 1990). Gynogenetic reproduction has some potential benefits: it allows the biomass of a population to be mainly composed of females, 
134

and available ecological resources can be solely used for egg production (Paschos et al., 2004).

C. gibelio has been reported in 1988, for the first time, in Gala Lake of Turkey (Baran and Ongan, 1988). Later on, reports from the Thrace Region (Özulug and Meriç, 1996; Özuluğ et al., 2004; 2005 a, b; İlhan et al., 2005; Tarkan et al., 2006; Gaygusuz et al., 2007) and the Anatolian Peninsula (İznik Lake-Tarkan et al., 2006; İznik Lake (Van)-Özuluğ et al., 2004; Büyük Menderes River Basin (Şaaşı and Balık, 2003; İlhan et al., 2005; Özcan, 2007; Sarı et al., 2008; Şaşı, 2008), Kızılırmak and Yeşilırmak Basins (İlhan et al., 2005; Yılmaz et al., 2007; Uğurlu and Polat, 2007; Bostanc1 et al., 2007 b; Kırankaya and Ekmekçi, 2013) and the Mediterranean region: the Lyca basin (Çıldır, 2001; Balık et al., 2005; Balık et al., 2003; Bostancı et al., 2007 a; Çınar et al., 2007) and Clicia Basin (Alagöz et al., 2006) has followed.

According to Yeğen et al. (2009), the indigenous species of Seyitler Reservoir are: Capoeta tinca (Heckel, 1843), Alburnus sp., Squalius cephalus (Linnaeus, 1758), Cobitis simplicispina (Hanko, 1925), Knipowitschia caucasica (Kawrajsky, 1899). The introduced species are: C. gibelio (Bloch, 1782) and Cyprinus carpio (Linnaeus, 1758).

Population sustainability must be maintained with natural sources/species. Therefore, management of natural sources based on scientific principles are needed. However, there are no studies, in the literature, on the growth properties of C. gibelio in Seyitler Reservoir. Therefore, the aim of this study is to examine the age composition, sex ratio, length and weight distributions, length-weight relationship and codition factor of $C$. gibelio samples which are eligible for fishing in Seyitler Reservoir. The results of the present study will be the basis of future research on this species and provide the necessary knowledge for fisheries and environmental management approaches.

\section{Materials and methods}

This study was carried out on a monthly basis between July 2005 to June 2006 in Seyitler Reservoir, in the Inner Aegean Region (3847’30.57” N, 3047'30.95” E). The Dam lake was built in 1964 for irrigation, and is fed by Seyitler Creek (Bulut, 2010). The sampling was performed using gill nets of various mesh sizes $(25 \times 25,30 \times 30,35$ x 35, $40 \times 40,45 \times 45 \mathrm{~mm}$ ). Collected fish were placed on ice in a cooler box and immediately transported to the laboratory. The fork lengths and weights were measured and weighted to the nearest $1 \mathrm{~mm}$ and $0.01 \mathrm{~g}$. Scales were used for age determination. Twenty to 25 scales were taken from each fish and used for age determination according to Lagler's method (Lagler, 1956). The scales were taken from the area between the dorsal fin and a lateral line region of the body side and examined under a binocular microscope. Sex was determined by macroscopic observation of the gonads.

To calculate length-weight relationships the equation of the Le Cren (1951),
$\mathrm{W}=\mathrm{a} \cdot \mathrm{L}^{\mathrm{b}}$, was used,

where $\mathrm{W}$ is the total weight of the fish $(\mathrm{g}), \mathrm{L}$ is the fork length $(\mathrm{cm})$, 'a' and ' $b$ ' are the parameters of the equation. The parameters ' $a$ ' and ' $b$ ' were estimated by linear regression of the transformed equation:

$\log W=\log a+b \log F L$.

The determination coefficient $\left(\mathrm{r}^{2}\right)$ was used as an indicator of the quality of the linear regression (Bagenal and Tesch, 1978).

The von Bertalanffy growth equations were determined:

$\mathrm{L}_{\mathrm{t}}=\mathrm{L}_{\infty}\left[1-\mathrm{e}^{\mathrm{k}(\mathrm{t}-\mathrm{t} \mathrm{o})}\right]$ and $\mathrm{W}_{\mathrm{t}}=\mathrm{W}_{\infty}\left[1-\mathrm{e}^{-\mathrm{k}(\mathrm{t}-\mathrm{t})}\right] \mathrm{b}$,

where $L_{t}$ and $W_{t}=$ fork length $(\mathrm{cm})$ and weight $(\mathrm{g})$ at age $t, \mathrm{~L}_{\infty}$ and $\mathrm{W}_{\infty}{ }^{\mathrm{t}}=$ asymptotic length and weight (the length and weight of the fish would reach at an infinity age), $\mathrm{k}=$ the growth coefficient, $\mathrm{t}=$ age of fish and $\mathrm{t}_{0}$ is the theoretical age the fish would have at length zero (Pauly, 1979). lows:

Condition factors were computed for each sex as fol-

$$
\mathrm{CF}=\left(\mathrm{W} / \mathrm{L}^{3}\right) \times 100
$$

where $\mathrm{W}$ is weight $(\mathrm{g}), \mathrm{L}$ is fork length $(\mathrm{cm})$, and ' $\mathrm{b}$ ' is the exponent of the length-weight relationship for females, males, and overall (Bagenal, 1978).

The growth performance index (phi-prime index) $\varnothing^{\prime}$ was computed from the equation:

$\varnothing^{\prime}=\operatorname{Ln} \mathrm{k}+2 \times \operatorname{Ln} \mathrm{L}_{\infty}$

where ' $\mathrm{k}$ ' and $\mathrm{L}_{\infty}$ are von Bertalanffy growth equation parameters (Sparre and Venema, 1992).

Differences between mean growth in males and females within the same age group were tested by Student's $t$ test. Statistical significance was set at 0.05 .

\section{Results}

In this study, a total of 149 C. gibelio specimens were investigated. Sex composition was $82.55 \%$ female, $16.11 \%$ male and $3.52 \%$ undetermined. Females were aged between II and VII; males between II and IV. It was observed that the dominant age was III $(84.56 \%)$ in all specimens and this was followed by ages II and IV (5.37\%) majority of the population consisted of females and it is possible that it is a monosexual, triploid and gynogenetic form (Tab. 1).

Tab. 1. Age and sex distribution of C. gibelio from Seyitler Reservoir

\begin{tabular}{ccccccc}
\hline \multirow{2}{*}{ Age } & \multicolumn{2}{c}{ Female } & \multicolumn{2}{c}{ Male } & \multicolumn{2}{c}{ Female+Male } \\
\cline { 2 - 7 } & $\mathrm{N}$ & $\%$ & $\mathrm{~N}$ & $\%$ & $\mathrm{~N}$ & $\%$ \\
\hline I & - & - & - & - & 2 & 1.34 \\
II & 5 & 3.36 & 1 & 0.67 & 6 & 4.03 \\
III & 104 & 69.8 & 22 & 14.77 & 126 & 84.56 \\
IV & 7 & 4.70 & 1 & 0.67 & 8 & 5.37 \\
V & 5 & 3.36 & - & - & 5 & 3.36 \\
VII & 2 & 1.34 & - & - & 2 & 1.34 \\
\hline
\end{tabular}


As seen in Tab. 2, mean fork-lengths of C. gibelio varied between 14.8 and $32.5 \mathrm{~cm}$. Eighty percent of the population was over $20 \mathrm{~cm}$ length. The longest individual was a female. This was obviously observed since the population's dominant length was between 20-21.9 cm (53.64\% ) (Fig. $1)$.

Tab. 2. Average fork lengths of C. gibelio and its relation with age $(\mathrm{cm})$

\begin{tabular}{ccccc}
\hline Age & N & Min & Max & Mean \pm SD \\
\hline I & 2 & 14.8 & 15.9 & $15.35 \pm 0.77$ \\
II & 6 & 17.0 & 20.1 & $17.74 \pm 1.72$ \\
III & 126 & 17.6 & 24.3 & $21.02 \pm 1.14$ \\
IV & 8 & 23.4 & 25.4 & $23.79 \pm 0.69$ \\
V & 5 & 25 & 27.3 & $25.56 \pm 1.08$ \\
VII & 2 & 31 & 32.5 & $31.75 \pm 1.06$ \\
\hline
\end{tabular}

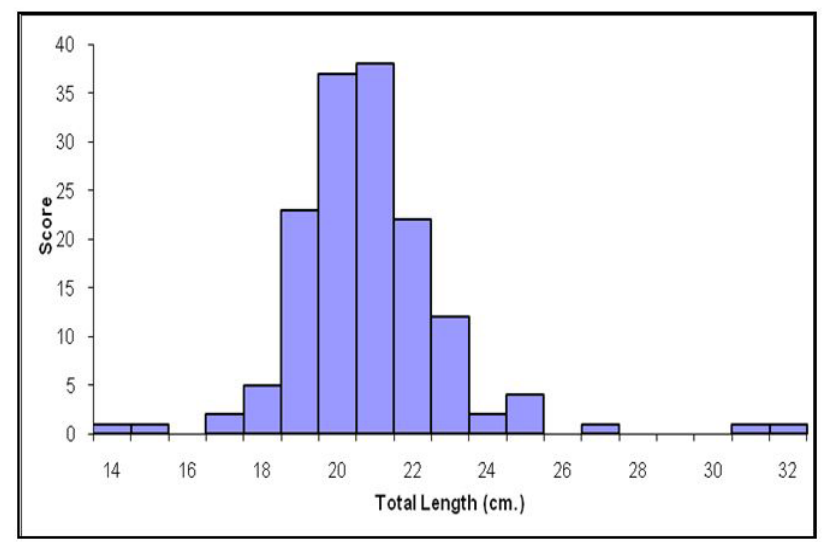

Fig. 1. Length-score distribution of C. gibelio

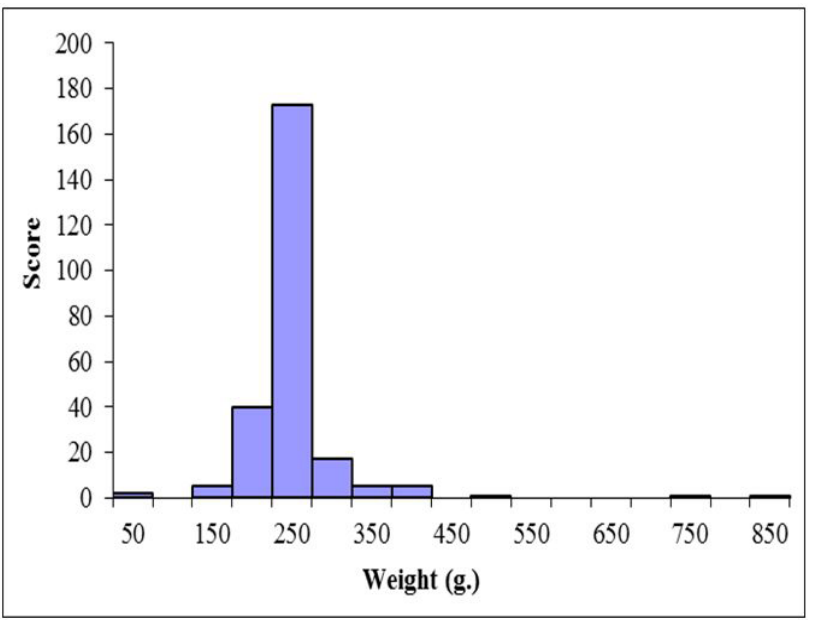

Fig. 2. Weight-score distribution of C. gibelio

As seen in Tab. 3, the weights of the individuals varied between 43.1 and $807.3 \mathrm{~g}$, and over $95 \%$ of the population were of $150 \mathrm{~g}$ weight. Most of the observed population was within the 200-249 g weight group (Fig. 2). Both length and weight increased with old age (Fig. 3, Fig. 4).
Tab. 3. Average weight and relationships with age groups of $C$. gibelio $(\mathrm{g})$

\begin{tabular}{ccccc}
\hline Age & N & Min & Max & Mean \pm SD \\
\hline I & 2 & 43.1 & 49.2 & $46.15 \pm 4.31$ \\
II & 6 & 115.2 & 205.5 & $130.6 \pm 58.56$ \\
III & 126 & 121.6 & 360.4 & $214.11 \pm 35.47$ \\
IV & 8 & 236.9 & 361.9 & $300.38 \pm 47.71$ \\
V & 5 & 284.6 & 451.5 & $348.46 \pm 68.01$ \\
VII & 2 & 703.5 & 807.3 & $755.4 \pm 73.39$ \\
\hline
\end{tabular}

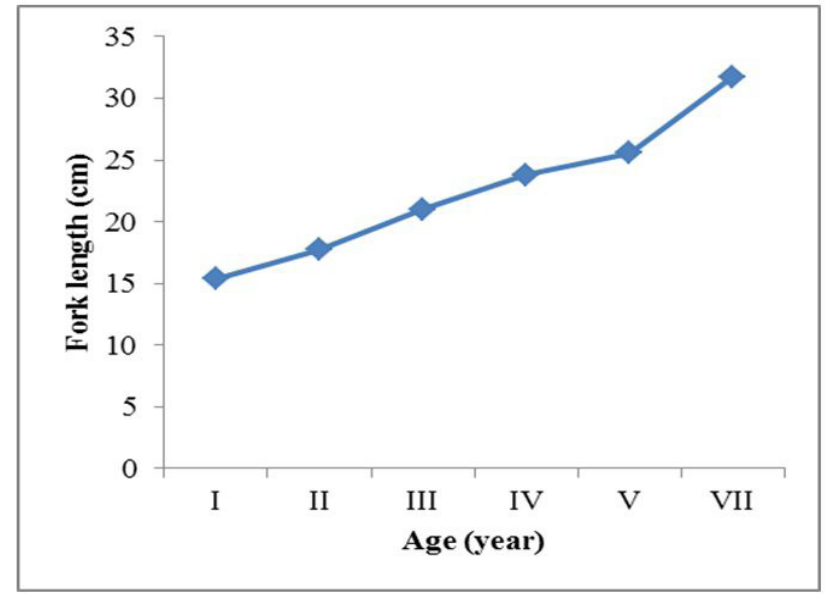

Fig. 3. Age-weight relationship of C. gibelio

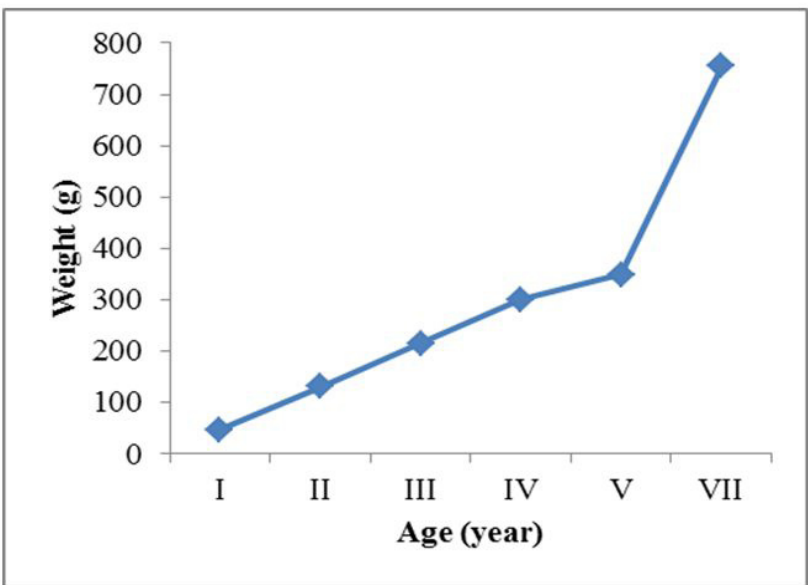

Fig. 4. Age-fork length relationship of C. gibelio

Results of statistical analysis ( $t$-test) showed that there were no statistically significant differences between both lengths, weight and sexes ( $p>0.05)$.

The mean condition factor was calculated as 2.064 for males, 2.342 for females, and 2.276 for female + male. The minimum and maximum range values were 1.223 and 2.974, respectively (Tab. 4).

Analysis of the average condition factor showed the highest level to be in the group VII age (2.359), and at the lowest level in the V age group (2.11) (Tab. 4). There was a statistically significant difference between average condition factors of the sexes $(p<0.05)$. 
136

The von Bertalanffy length growth and weight equations for all individuals of C. gibelio living in Seyitler Reservoir were found to be $\mathrm{L}_{\mathrm{t}}=48.09\left[1-\mathrm{e}^{-0.093(\mathrm{t}+0.29)}\right]$, and $\mathrm{W}_{\mathrm{t}}=2323.62\left[1-\mathrm{e}^{-0.093(\mathrm{t}+0.29)}\right]^{2.9382}$, respectively. The $\varnothing^{\prime}$ value was calculated as 5.37 using $\mathrm{L}_{\infty}$ and $\mathrm{k}$ values. The relationship between length-weight, was calculated by using their length and weight, and was found at: and was found at: $\mathrm{W}=0.0696 \mathrm{~L}^{2.132}, \mathrm{r}=0.838$ for females, for males $\mathrm{W}=$ $0.2942 \mathrm{~L}^{2.6417} \mathrm{r}=0.784$ and $\mathrm{W}=0.0274 \mathrm{~L}^{2.9382}, \mathrm{r}=0.813$ for female + male and related graph was given in Fig. 5 . A negative allometric growth was detected in the population.

Tab. 4. Average condition factors with the relation of age groups of C. gibelio

\begin{tabular}{ccccccc}
\hline Age & N & Female & N & Male & N & $\begin{array}{c}\text { Female+ } \\
\text { Male }\end{array}$ \\
\hline I & - & - & - & - & 2 & 1.28 \\
II & 5 & 2.47 & 1 & 2.37 & 6 & 2.46 \\
III & 104 & 2.36 & 22 & 2.05 & 126 & 2.31 \\
IV & 7 & 2.14 & 1 & 2.06 & 8 & 2.13 \\
V & 5 & 2.11 & - & - & 5 & 2.11 \\
VII & 2 & 2.36 & - & - & 2 & 2.36 \\
Total & 123 & 2.34 & 24 & 2.07 & 149 & 2.28 \\
\hline
\end{tabular}

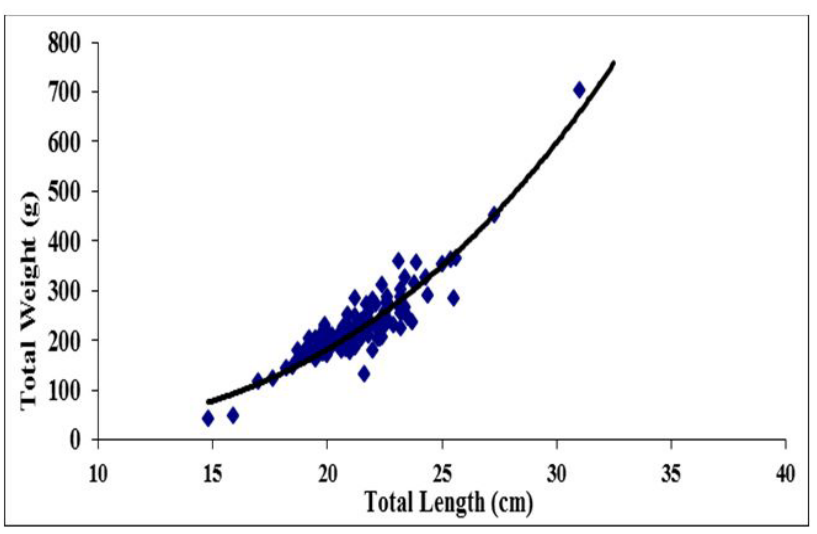

Fig. 5. Length-weight relationship of C. gibelio

\section{Discussion}

The introduction of invasive alien species is considered to be a leading cause of species endangerment and extinction in freshwater systems. Inland water ecosystems are particularly vulnerable to invasive alien species. The understanding of population biology of invaders and the effect of introduced species is necessary for constructing a robust theory of invasion biology that would provide a basis for rational decisions about species introduction and eradication efforts (Simberloff, 2003). The gibel carp is an invasive fish species for Seyitler Reservoir, Turkey.

Studies on C. gibelio have reported the following age groups: I-IV in Eğirdir Lake (Balık et al., 2004) III-VI in Menderes Lake (Şaşı, 2008); II-VII in Bafra Fish Lake
(Bostancı et al., 2007a); 0-V in Beyşehir Lake (Çınar et al., 2007); 0-V in Gelingüllü Reservoir (Kırankaya and Ekmekçi, 2013); I-VI in Buldan Reservoir (Sar1 et al., 2008); I-VI in Ömerli Reservoir I-IV, in İznik Lake (Tarkan et al., 2008); I-VII shore and inner side waters of Estonia (Vetemaa et al., 2005).

The results of the present study have shown that individuals of C. gibelio population is between I-VII ages old. This age range is similar to those reported for Bafra Fish Lake (Bostanc1 et al., 2007b) and Ulubat Lake (Emiroğlu, 2008). In addition it is similar to the case of the Eğirdir Lake (Özkök et al., 2007) except for the $0 \pm I X$ age range. Oldest age is IV in male individuals and VII in females. Similar results were reported by Balık et al. (2004), Özkök et al. (2007), Sarı et al. (2008) and Emiroğlu (2008). According to these results it is obvious that male individuals have shorter life spans that females.

In previous reports, the male/female ratios for Turkish fresh water systems were 1.14/1 in Eğirdir Lake (Balık et al., 2004); 0.03/1 Bafra Fish Lake (Bostanc1 et al., 2007b); 1.46/1 in Eğirdir Lake (Bostancı et al., 2007a); 0.92/1 in Beyşehir Lake (Çınar et al., 2007); 1.08/1 in Eğirdir Lake (Özkök et al., 2007) 0.52/1 in Ulubat Lake (Emiroğlu, 2008); 0.005/1 in Buldan Reservoir (Sarl et al., 2008); 0.07 in Ömerli Reservoir, 0.63/1 in İznik Lake (Tarkan et al., 2008); 0.026/1 in Pomvotis Lake (Tsoumani et al., 2006). In our study it is $0.19 / 1$. In other studies this ratio was reported to be close to $1 / 1$. The studies on $C$. gibelio introduced into Eğirdir Lake in the early 1990s, and dominated the Lake immediately, have shown that the male/ female ratio was high in the beginning; however later it recessed close to 1/1. The ratio of 0.19/1 in Seyitler Reservoir shows that female individuals dominate due to gynogenetic reproduction of $C$. gibelio (Buth et al., 1991). Gynogenetic reproduction which may be undesirable for other species in the same habitat may have caused an increase in the number of female individuals in the C. gibelio population of Eğirdir Lake. This trend continues in Eğirdir Lake and Seyitler Reservoir should be monitored for economic benefits.

In this study, mean condition factor of males, females and the combined sex were calculated as 2.342, 2.064 and 2.276 , respectively. The condition values were similar to other published results in Turkey (Özkök et al., 2007; Çınar et al., 2007) and were lower than those reported by Bostanci et al. (2007b), Balık et al. (2004), Kirankaya and Ekmekçi (2013). Differences in condition coefficients may change within the same species depending on age, season, sexual maturity, spawning period, feeding condition and environmental conditions (Çetinkaya et al., 2005).

The phi-prime test $\left(\varnothing^{\prime}\right)$ which reflects the overall growth performance was used to evaluate the reliability of the growth parameter (Pauly and Munro, 1984). The growth performance value of the C. gibelio population in the Seyitler Reservoir was 5.37. This value is also close to the ones obtained in Beyşehir Lake $\left(\varnothing^{\prime}=5.59\right)$, (Çınar 
et al., 2007) and Eğirdir Lake ( $\left.\varnothing^{\prime}=5.91\right)$, (Balık et al., 2004). The growth performance of $C$. gibelio population in Seyitler Reservoir was found to be lower than other lakes except for Buldan Reservoir $\left(\varnothing^{\prime}=4.8\right)$, (Sar1 et al., 2008) among the Turkish lakes studied. This is probably related to the homogeneity of ecological situations such as food abundance and water temperature of the habitats (Alp et al., 2005)

The length-weight relationship of the crucian carp population in Seyitler Reservoir was $\mathrm{W}=0.0274 \times \mathrm{L}^{2.938}$. The slope value of the length-weight relationship showed that body weight negative allometric growth was detected in with fork length. Similar results were reported by Kizına (1986), Bostancı et al. (2007b), Kırankaya and Ekmekçi (2013) and Sar1 et al. (2008) as 2.87, 2.97, 2.90 and 2.87, respectively. However, different results were also reported by Bostanci et al. (2007a), Balık et al. (2004), Tarkan et al. (2006), Tsoumani et al. (2006) and Özkök et al. (2007) as 3.177, 3.152, 3.237, 3.28 and 3.128, respectively. These variations could be attributed to differences in age, maturity and sex. Geographic location and associated environmental conditions, such as seasonality, stomach fullness, disease and parasite loads, can also affect the value of $b$ (Bagenal and Tesh, 1978).

The mean fork lengths and weights of the specimens from the study area were $14.8-32.5 \mathrm{~cm}$, and $43.1-807.3 \mathrm{~g}$. These values were reported from Bafra Fish Lake as 16.9$30 \mathrm{~cm}$ and 125-730 g (Bostanc1 et al., $2007 \mathrm{~b}$ ); 7.1-27.4 $\mathrm{cm}$ and 6-495 g from Beyşehir Lake (Çınar et al., 2007); 9.7-25.5 cm and 23.6-269.1 $\mathrm{g}$ from Buldan Reservoir (Sar1 et al., 2008); and 8.2-28.1 cm and 17-732 $\mathrm{g}$ from Eğirdir Lake (Bostanc1 et al., 2007 a). These values show Seyitler Reservoir specimens to be larger than C. gibelio from other lakes.

The maximum length $\left(\mathrm{L}_{\infty}\right)$ and maximum weight $\left(\mathrm{W}_{\infty}\right)$ of C. gibelio were reported as follows: $36.2 \mathrm{~cm}$ and 1285.6 $\mathrm{g}$ for Beyşehir Lake, $31.66 \mathrm{~cm}$ and $627.18 \mathrm{~g}$ for Buldan Reservoir, $33.3 \mathrm{~cm}$ and $1038.1 \mathrm{~g}$ for Eğirdir Lake (Balık et al., 2004). These values were expected to be $48.09 \mathrm{~cm}$ and $2323.62 \mathrm{~g}$ for the study area's fish specimens in regards to the calculation of von Bertalanffy. The results show our fish to have much higher value than others, and this could be explained by ecological differences among the localities mentioned.

Based on these results and extrapolations, it is obvious that $C$. gibelio are in competition for food with the highly economically valued $C$. carpio and other local fish $(C$. tinca (endemic), Alburnus sp., S. cephalus, C. simplicispina (endemic), $K$. caucasica) due to its omnivorous feeding behavior. To control population density, fishing should be allowed in all seasons and a long-term continuous monitoring program for the species is highly recommended. Although present no risk is foreseen on native fish stocks yet; the monitoring of fish stocks, especially on protected fauna species, should be made periodically to sustainable exploitation and to protect biodiversity.

\section{References}

Alagöz S, Ergüden D, Göksu MZL (2006). First time determination fish species in Seyhan Dam Lake. Stocking and Reservoir Management Sympo Proc I, 7-9 February 2006, Antalya, Turkey. T. K. B. Mediterranean Fisheries Research Production and Education Institute, Antalya.

Alp A, Kara C, Büyükçapar HM, Bülbül O (2005). Age, growth and condition of Capoeta capoeta angorae Hanko 1924 from the upper water systems of the river Ceyhan. Turk J Vet Anim Sci 29:665-676.

Andersen MC, Adams H, Hope B, Powell M (2004). Risk assessment for invasive species. Risk Anal 24:787-793.

Bagenal TB (1978). Methods for assessment of fish production in freshwaters. Blackwell Scientific Publications, London, $365 \mathrm{p}$.

Bagenal TB, Tesh FW (1978). Age and growth. Methods for assessment of fish population in fresh waters. IBP Handbook No 3, Blackwell Scientific Publications, Oxford, 101-136 p.

Balık I, Karaşahin B, Özkök R, Çubuk H, Uysal R (2003). Diet of silver crucian carp Carassius gibelio in lake Eğirdir. Turk J Fisheries Aquatic Sci 3:87-91.

Balık I, Özkök R, Çubuk H, Uysal R (2004). Investigation of some biological characteristics of the silver crucian carp Carassius gibelio (Bloch 1782) population in lake Eğirdir. Turk J Zool 28:19-28.

Baran I, Ongan T (1988). Limnological features of lake Gala, fisheries problems and suggestions. Gala Lake and Problems Symposium, Wildlife Conservation Society Publications Series, Istanbul.

Bostancı D, Polat N, Akyürek M (2007a). Some biological aspects of the crucian carp, Carassius gibelio (Bloch, 1782) inhabiting in Eğirdir lake. Intern J Natural Engin Sci 1(3):5558.

Bostancı D, Polat N, Kandemir Ş, Yılmaz Ş (2007b). Determination of condition factor and lenght-weight relationship of the crucian carp, Carassius gibelio (Bloch, 1782) inhabiting Bafra Fish lake. SDÜ Fen Edebiyat Fakültesi Fen Dergisi 2 (2):117-125.

Buth DG, Dowling TE, Gold JR (1991). Molecular and cytological investigation, 83-126 p. In: Winfield IJ, Nelson JS (Eds.). Cyprinid Fishes: Systematics, Biology and Exploitation, Chapman and Hall, London.

Bulut $S$ (2010). The variation of the fatty acid composition in muscle tissue of Carassius gibelio living in Seyitler Dam lake (Afyonkarahisar). Electron J Food Technol 5(2):69-75.

Çıldır H (2001). Introduction of exotic vertebrates in Turkey: A review and an assessment of their impact. Middle East Technical Univ, $101 \mathrm{p}$.

Çınar Ş, Çubuk H, Özkök R, Tümgelir L, Çetinkaya S, Erol KG, Ceylan M (2007). Growth features of silver crucian carp (Carassius gibelio Bloch, 1782) population in lake Beyşehir. Turk J Aquatic Life 5(8):401-409. 
138

Emiroğlu Ö (2008). Determination on some bio-ecology of Esox lucius (Linnaeus, 1758), Carassius gibelio (Bloch, 1782) and Scardinius erythophthalmus (Linnaeus, 1758) populations inhabiting Uluabat lake (Bursa). Univ of Eskişehir Osmangazi, Institute of Sci, PhD Thesis, $155 \mathrm{p}$.

Fan Z, Shen J (1990). Studies on the evolution of bisexual reproduction in crucian carp (Carassius auratus gibelio Bloch, 1782). Aquaculture 84:235-244.

Gaygusuz Ö, Tarkan AS, Gürsoy Ç, Gaygusuz G (2007). Changes in the fish community of the Ömerli Reservoir (Turkey) following the introduction of non-native Gibel carp Carassius gibelio (Bloch, 1782) and other human impacts. Aquatic Invasions 2(2):117-120.

Gurevitch J, Padilla DK (2004). Are invasive species a major cause of extinctions? Trends Ecol Evol 19:470-474.

İlhan A, Balık S, Sarı HM, Ustaoğlu MR (2005). Carassius (Cyprinidae, Pisces) species in inland waters of western and Middle Anatolia, Southern Marmara, Thrace and Western Black Sea Regions and their distribution. EÜ J Fish Aqua Sci 22:343-346.

İzci L (2004). Some population parameters of Carassius auratus (L., 1758) in lake Eğirdir. Turk J Vet Anim Sci 28:23-27.

Kırankaya ŞG, Ekmekçi FG (2013). Life-history traits of the invasive population of prussian carp, Carassius gibelio (Actinopterigi: cypriniformes: cyprinidae), from Gelingüllü Reservoir, Yozgat, Turkey. Acta Ichthyol et Piscatoria 43(1):3140 (in Turkish).

Kızına LP (1986). Some data on the biology of the genus Carassius from the lower reaches of the Volga Delta. J Ichthyology 26(4):31-40.

Lagler KF (1956). Freshwater Fish Biology. Wm C Brown Company, Dubuque, Iowa, $421 \mathrm{p}$.

Le Cren ED (1951). The length-weight relationship and seasonal cycle in gonad weight and condition in Perch, Perca fluviatilis. J Anim Ecol 20:201-219.

Özkök R, Çubuk H, Tümgelir L, Uysal L, Çınar Ş, Küçükkara R, Erol KG, Ceylan M (2007). Growth features of Silver Crucian Carp (Carassius gibelio Bloch, 1782) population in Lake Eğirdir. Turk J Aquatic Life 3(5):313-322 (in Turkish).

Özcan G (2007). Distrubition of non-indigenous fish species, Prussian carp Carassius gibelio (Bloch, 1782) in the Turkish freshwater systems. Pak J Biol Sci 10 (23):4241-4245.

Özuluğ M, Meriç N (1996). On the fishes of Büyükçekmece Dam Lake. XIII. National Biology Congress, 17-20 September 1996, İstanbul 5:109-117.

Özuluğ M, Meriç N, Freyhof J (2004). The distribution of Carassius gibelio (Bloch, 1782) (Teleostei: Cyprinidae) in Thrace (Turkey). Zool in the Middle East 31:63-66.

Özuluğ M, Altın O, Meriç N (2005a). On the fish fauna of lake İznik (Turkey). Turk J Zool 29:371-375.

Özuluğ M, Acıpınar H, Gaygusuz Ö, Gürsoy Ç, Tarkan AS (2005b). Effects of human factor on the fish fauna in a drinking-water resource (Ömerli Dam Lake- İstanbul, Turkey). Res J Agric Biol Sci 1:50-55.

Paschos I, Nathanailides C, Tsoumani M, Perdikaris C, Gouva E, Leonardos I (2004). Intra and inter-specific mating op- tions for gynogenetic reproduction of Carassius gibelio (Bloch, 1783) in lake Pamvotis (NW Greece). Belg J Zool 134(1):55-60.

Pauly D (1979). Gill size and temperature as governing factors in fish growth: A generalization of von Bertalanffy's growth formula. Berichte Ins F Meereskunde (Kiel) 63:156.

Pauly D, Munro JL (1984). Once more on the comparison of growth in fish and vertebrates, ICLARM Fishbyte 2(1):21.

Riehl R, Baensch HA (1991). Aquarien Atlas. Bd. 3. Melle : Mergus, Verlag fr Natur-und Heimtierkunde, Germany $1104 \mathrm{p}$.

Saat T (1990). Morphology and chronology of maturation in oocytes of diploid and triploid forms of silver crucian carp, Carassius auratus gibelio Bloch in vitro. Soviet J Dev Biol 20:267-276.

Sarı HM, Balık S, Ustaoğlu MR, İlhan A (2008). Population structure, growth and mortality of Carassius gibelio (Bloch, 1782) in Buldan Dam Lake. Turk J Fisheries Aquatic Sci $8: 25-29$.

SimberloffD (2003). Confronting introduced species: a form of xenophobia? Biol Invasions 5:179-92.

Specziar A, Tolg L, Biro P (1997). Feeding strategy and growth of Cyprinids in the littoral zone of lake Balaton. J Fish Biol 51:1109-1124.

Sparre P, Venemaa SC, (1992). Introduction to tropical fish stock assessment-Part 1: Manual. FAO Fish. Tech. Pap 306/1, Rome, 376 p.

Şaşı H (2008). The length and weight relations of some reproduction characteristics of Prussian carp, Carassius gibelio (Bloch, 1782) in the South Aegean region (Aydın-Turkey). Turk J Fisheries Aquatic Sci 8:87-92.

Şaşı H, Balık S (2003). The distribution of three exotic fishes in Anatolia. Turk J Zool 27:319-322.

Tarkan AS, Gaygusuz Ö, Gürsoy Ç, Acıpınar H, Bilge G (2006). A new predator species Carassius gibelio, (Bloch, 1782): Successful or not? I. Balıklandırma ve Rezervuar Yönetimi Sempozyumu Bildirileri, 7-9 February 2006, Antalya, Turkey. T. K. B. Mediterranean Fisheries Research Production and Education Institute, Antalya.

Tsoumani M, Liasko R, Moutsaki P, Kagalou I, Leonardos I (2006). Length-weight relationships of an invasive cyprinid fish (Carassius gibelio) from 12 Greek lakes in relation to their trophic states. J Appl Ichthyol 22:281-284.

Vetemaa M, Eschbahum R, Albert A, Saat T (2005). Distribution, sex ratio and growth of Carassius gibelio (Bloch, 1782) in coastal and inland water of Estonia (north-eastern Baltic Sea). J Applied Ichthyol 21:287-291.

Yeğen V, Balık S, Bostan H, Sarı HM, Yağcı A, İlhan A (2009). Fish fauna of the Dam lakes and Ponds in Afyonkarahisar (Turkey), XV. Ulusal Su Ürünleri Sempozyumu, 1-4 Temmuz, $119 \mathrm{p}$.

Zhou L, Wang Y, Gui J (2000). Genetic evidence for gonochristic reproduction in gynogenetic silver crucian carp (Carassius auratus gibelio Bloch, 1782) as revealed by RAPD assays, J Molec Evol 51:498-506. 